\title{
Polyphosphoinositide Phosphatase
}

National Cancer Institute

\section{Source}

National Cancer Institute. Polyphosphoinositide Phosphatase. NCI Thesaurus. Code C124945.

Polyphosphoinositide phosphatase (907 aa, 104 kDa) is encoded by the human FIG4 gene. This protein plays a role in the mediation of polyphosphoinositide metabolism. 